\title{
MODIFIKASI PATI BIJI NANGKA SECARA FISIK DAN KIMIA
}

\author{
Nurul Azizah Choiriyah ${ }^{\mathbf{1}}$, Ashri Mukti Benita ${ }^{2}$, Arya Putra Sundjaja ${ }^{\mathbf{1}}$, \\ ${ }^{1}$ Program studi Seni Kuliner, Akademi Kuliner dan Patiseri OTTIMMO Internasional, Jawa Timur \\ ${ }^{2}$ Fakultas Sains dan Teknologi, Program studi Teknologi Pangan, Universitas Nahdlatul Ulama Purwokerto \\ Email: nurul.azizah.choiriyah@gmail.com
}

Diserahkan: 21 Juli 2020

Diterima: 7 Desember 2020

\begin{abstract}
Modification of jackfruit seed starch can be carried out by physical (annealing, heat moisture treatment, pre-gelatinization and extrution) and chemical (etherification, carboxymetilation, esterification, cross linking and oxidation). Modification of jackfruit seed starch can improve the physico-chemical properties of native jackfruit seed starch. The physico-chemical properties change allows the use of modified jackfruit seed starch in the food industry. This review covers topics including the method and the physico-chemical properties of modified jackfruit seed starch.
\end{abstract}

Keywords: jackfruit seed starch, starch granule, starch modification, starch functional properties

\section{PENDAHULUAN}

Biji nangka merupakan limbah industri buah kaleng yang telah menarik perhatian para peneliti untuk dibuat sumber pati baru. Sifat fisikokimia dan fungsional pati biji nangka maupun pati biji nangka termodifikasi fisik dan kimia telah banyak dikaji, hasilnya menunjukkan bahwa pati tersebut dapat diaplikasikan pada produk makanan, pangan fungsional dan produk farmasi. Biji nangka merupakan sumber karbohidrat sekitar 63-80 $\%$ (Roy Chowdhury et al., 2012); (EkeEjiofor, 2014); (Madrigal-Aldana et al., 2011). Biji nangka mengandung pati sekitar 20-25\% dan amilosa yang tinggi (24-32\%). Pati biji nangka alami termasuk sumber pati resisten tipe 2. Pati resisten merupakan jenis pati yang tidak dapat dihisrolisis oleh enzim pada usus. Kadar pati resisten pada pati biji nangka sekitar 29,7 \% (O. S. Kittipongpatana \& Kittipongpatana, 2015). Pati biji nangka menunjukkan tingkat kecernaan yang rendah (Zhang et al., 2019).

Pati biji nangka telah digunakan aplikasinya pada produk pangan sebagai bahan pengikat dan stabilizer (Rengsutthi \& Charoenrein, 2011). Namun karakteristiknya membuat aplikasinya terbatas misalnya ketidaklarutan dalam air, kemampuan pengembangan (swelling) yang terbatas, kemampuan dispersibilitas granula rendah dan sineresis (Madrigal-Aldana et al., 2011). Teknologi modifikasi pati dapat memperbaiki karakteristik dari pati alami. Beberapa teknik, metode dan agen telah digunakan oleh para peneliti dalam memproduksi pati modifikasi biji nangka. Penelitian tersebut berhasil meningkatkan karakteristik pati alami sehingga cocok diaplikasikan pada industri pangan maupun farmasi (O. S. Kittipongpatana \& Kittipongpatana, 2011).

Modifikasi pati biji nangka dapat dilakukan dengan cara kimia (eterifikasi, 
karboksimetilasi, esterifikasi, ikatan silang dan oksidasi) dan cara fisik (annealing, perlakuan panas lembab, pregelatiniasasi dan ekstrusi) (Abbas et al., 2010). Penggunaan pati biji nangka termodifikasi dalam dunia industri pangan antara lain sebagai bahan pengental, bahan pembentuk gel, bahan pengisi (Zhang et al., 2019), bahan penyalut pada proses enkapsulasi (Zhu et al., 2018). Review ini bertujuan untuk merangkum metode dan sifat fisiko-kimia pati modifikasi biji nangka.

\section{MODIFIKASI FISIK PATI BIJI NANGKA}

Modifikasi pati secara fisika telah banyak digunakan untuk meningkatkan sifat fisik dan kimia pati serta karakteristik fungsional dibandingkan sifat pati asalnya (L. F. Wang et al., 2010). Modifikasi pati secara fisik dilaporkan dapat menurunkan polimerisasi rantai pati yang menghasilkan perubahan karakteristik fungsional seperti penurunan viskositas, peningkatan kelarutan dan kapasitas pengikatan air (Polesi \& Sarmento, 2011)

Modifikasi secara fisik diantaranya dapat dilakukan dengan cara penggunaan alat autoclave disertai dengan pendinginan, hidrolisis asam dikombinasikan dengan proses autoclave dan pendinginan (Dundar \& Gocmen, 2013), pati yang digelatinisasi secara parsial atau pati pregelatinisasi menggunakan perlakuan pemanasan (Tran et al., 2015), teknologi ekstrusi (Zhang et al., 2019), annealing (Bhattacharjya et al., 2015) dan perlakuan panas lembab (O. S. Kittipongpatana \& Kittipongpatana, 2015).

\section{Modifikasi dengan pemanasan}

(Tran et al., 2015) melakukan modifikasi fisik pati biji nangka dengan pemanasan untuk menghasilkan pati tergelatinisasi secara parsial. Prosedur pada penelitian tersebut sebagai berikut pati biji nangka didispersikan pada air distilasi dengan rasio air: pati $=3: 7$ pada suhu ruang. Setiap batch dispersi kemudian dipanaskan pada suhu $70^{\circ} \mathrm{C}$ selama 20, 30 dan 60 menit. Kemudian pati yang tergelatinisasi secara parsial didinginkan dan volume etanol sebanyak 2 kali dari pati ditambahkan dan dilakukan pengadukan secara kontinyu. Etanol kemudian dihilangkan melalui sentrifugasi. Pati biji nangka yang telah tergelatinisasi parsial tersebut kemudian didinginkan menggunakan oven pengering suhu $40^{\circ} \mathrm{C}$ selama 24 jam.

Penelitian pati nangka pregelatiniasi juga telah dilakukan oleh (O. S. Kittipongpatana \& Kittipongpatana, 2011). Produksi pati nangka pregelatinisasi dilakukan dengan mengendapkan pati nangka sebanyak $100 \mathrm{~g}$ ke dalam $350 \mathrm{ml}$ air distilasi dengan memanaskan pada suhu $80^{\circ} \mathrm{C}$ selama 15 menit. Selama pemanasan dilakukan pengadukan secara terus menerus. Pasta pati kemudian didinginkan selanjutnya ditambahkan $200 \mathrm{ml}$ metanol dan diaduk. Metanol kemudian dihilangkan dan pati dikeringkan pada suhu $40^{\circ} \mathrm{C}$.

Pati biji nangka yang dipanaskan menggunakan suhu $70^{\circ} \mathrm{C}$ dilaporkan dapat menghilangkan bagian endotherm pertama (puncak I) dengan tetap mempertahankan kristalinitasnya yang tinggi (puncak II) ketika 
dianalisis dengan DSC. Hal ini berarti bahwa pati biji nangka tersebut mengalami gelatinisasi sebagian dan bagian lain tetap tidak tergelatinisasi. Pati biji nangka tergelatinisasi parsial menunjukkan kapasitas pengikatan air yang lebih tinggi jika dibandingkan dengan pati alaminya jika diuji dengan Water sorption isothermis. Pati biji nangka tergelatinisasi parsial telah menarik pada berbagai industri untuk penemuan pati baru (Tran et al., 2015). Penelitian Tran et al (2015) senada dengan penelitian (O. S. Kittipongpatana \& Kittipongpatana, 2011), dimana pati nangka dengan pregelatinisasi memiliki peningkatan kapasitas pengikatan air. Pati nangka tersebut juga menunjukkan peningkatan kelarutan, penyerapan air dan suhu gelatinisasi. Aplikasi pati biji nangka pada industri pangan yaitu digunakan sebagai bahan pengikat.

\section{Modifikasi dengan panas lembab}

Modifikasi pati secara panas lembab merupakan metode hydrothermal yang telah digunakan untuk memperbaiki sifat fisikokimia, sifat fungsional dan kecernaan dengan efek minimum pada struktur granul. Perlakuan panas lembab dilakukan pada kadar air $35 \%$ (b/b) atau di bawahnya (10.3, 20, 25 dan $30 \%$ ) dan pada suhu antara glass transition dan suhu gelatinisasi (80, 90, 100, 110 dan $120^{\circ} \mathrm{C}$ ) dengan waktu paparan 6,12 dan 16 jam. Modifikasi panas lembab menyebabkan peningkatan suhu gelatinisasi sebagaimana peningkatan kadar air sampel (Li et al., 2011). Pati biji nangka yang mengalami perlakuan panas lembab mengalami peningkatan kadar pati resisten. Pada sampel pati biji nangka termodifikasi panas lembab dengan kadar air $30 \%$ dan suhu pemanasan $80^{\circ} \mathrm{C}$ mengalami peningkatan pati resisten yang sangat tajam, kemudian perlakuan dengan kadar air $30 \%$ dan suhu pemanasan yang lebih tinggi yaitu 100 dan $120^{\circ} \mathrm{C}$ dapat menurunkan kadar pati resisten. Penurunan kadar pati resisten dengan perlakuan suhu yang lebih tinggi $\left(100\right.$ dan $\left.120^{\circ} \mathrm{C}\right)$ dikarenakan oleh adanya peristiwa gelatinisasi parsial (O. S. Kittipongpatana \& Kittipongpatana, 2015). Hal ini juga terjadi pada penelitian (Ambigaipalan et al., 2014) yang memodifikasi pati biji faba dengan panas lembab, pati biji faba termodifikasi panas lembab mengalami peningkatan kadar pati resisten yang tajam pada suhu pemanasan $80^{\circ} \mathrm{C}$ kemudian kadar pati resisten mengalami penurunan pada suhu pemanasan $120^{\circ} \mathrm{C}$.

Pati biji nangka termodifikasi panas lembab memiliki kadar amilosa sekitar 24,7-28,4\%. Semakin tinggi kadar amilosa pati biji nangka termodifikasi panas lembab maka semakin tinggi pula kadar pati resistennya (O. S. Kittipongpatana \& Kittipongpatana, 2015). Hal ini juga terjadi pada pati biji kacang hijau, kadar amilosa berbanding lurus dengan kadar pati resisten (Li et al., 2011).

Pati biji nangka alami memiliki sifat pengembangan dalam air dan mengalami peningkatan yang tajam pada suhu $70^{\circ} \mathrm{C}$, kemudian terjadi peningkatan yang signifikan pada suhu $80^{\circ} \mathrm{C}$ serta terus meningkat pada 
suhu $90^{\circ} \mathrm{C}$. Pati biji nangka termodifikasi secara panas lembab menunjukkan penurunan pengembangan dalam air pada suhu $50-70^{\circ} \mathrm{C}$ dan hanya menunjukkan peningkatan yang tajam pada suhu $80^{\circ} \mathrm{C}$ dan peningkatan yang moderat (sedang) pada suhu $90^{\circ} \mathrm{C}$. Penurunan kekuatan pengembangan dalam air dikarenakan penyusunan kembali granula pati, penurunan hidrasi dan interaksi antara amilosa-amilopektin maupun interaksi amilosa-amilosa akibat perlakuan panas lembab. Pati biji nangka termodifikasi panas lembab menghasilkan pati yang memiliki kandungan tinggi pati resisten yang dapat dipalikasikan pada pembuatan es krim yang memiliki efek prebiotik dan yoghurt (O. S. Kittipongpatana \& Kittipongpatana, 2015).

\section{Modifikasi dengan annealing}

Modifikasi pati dengan annealing merupakan modifikasi pati dengan melibatkan perlakuan panas ringan dengan jumlah air yang berlebih. Suhu yang digunakan adalah di atas suhu glass transition namun di bawah suhu gelatinisasi pati. Annealing dapat merubah sifat fisiko-kimia pati namun perubahan pada granula pati dan sifat kristalinitas sangat sedikit. Teknik annealing dapat dilakukan dengan single step annealing dan double step annealing. Single step annealing pati biji nangka dilakukan dengan cara memanaskan $10 \mathrm{~g}$ pati alami biji nangka pada $50 \mathrm{ml}$ air distilasi pada suhu 45, 50,55, $60^{\circ} \mathrm{C}$ selama 72 jam menggunakan shaking waterbath. Double step annealing dilakukan dengan pemanasan awal tambahan suhu $10^{\circ} \mathrm{C}$ di bawahnya, suhu yang ditentukan di atas dengan durasi yang sama. Sampel yang telah melalui annealing kemudian disentrifugasi $5000 \mathrm{rpm}$ selama 5 menit, residu yang dikumpulkan kemudian dikeringkan pada suhu $40^{\circ} \mathrm{C}$, diayak dengan ayakan $100 \mu \mathrm{m}$.

Pati biji nangka termodifikasi secara annealing memiliki tingkat pengembangan yang lebih rendah daripada pati biji nangka alami. Hal ini terjadi karena peningkatan kristalinitas pada pati biji nangka termodifikasi annealing. Melalui pengamatan X-ray diffraction, terjadi peningkatan kristalinitas pada pati biji nangka termodifikasi annealing dibandingkan dengan pati biji nangka alami. Pati biji nangka termodifikasi secara single step annealing memiliki kristalinitas yang lebih tinggi daripada metode double step annealing. Hal ini dikarenkan pada teknik double step annealing, sebagian kristalin yang terbentuk pada proses pemanasan pertama sifatnya labil, dan struktur tetap dipertahankan menengah antara amorf dan kristalin kemudian pada proses pemanasan kedua terjadi kehilangan kristalin. Pati biji nangka termodifikasi annealing juga memiliki kelarutan yang lebih rendah daripada pati biji nangka alami. Penurunan tingkat pengembangan dan kelarutan mengakibatkan peningkatan kekerasan gel. Sifat kristalinitas yang tinggi pada pati biji nangka termodifikasi secara single step annealing memungkinkan penggunaannya pada produk mie (Bhattacharjya et al., 2015)

\section{Modifikasi dengan ekstrusi}


Sebagai modifikasi secara fisik, teknologi pengolahan secara ekstrusi dapat memperbaiki karakteristik pati mentah sehingga dapat diaplikasikan pada pembuatan sereal sarapan dan produk makanan ringan dengan meningkatkan kecernaan pati. Melalui teknologi ekstrusi, pati biji nangka termodifikasi dapat dipecah oleh enzim amilase dengan waktu yang lebih cepat daripada pati biji nangka alami. Hal ini berarti bahwa teknologi ekstrusi dapat meningkatkan pencernaan dan penyerapan makanan pada usus halus. Hasil penelitian menunjukkan bahwa kadar pati resisten pada pati biji nangka termodifikasi dengan ekstrusi menjadi menurun dibandingkan dengan pati biji nangka alami.

Penggunaan teknologi ekstrusi secara umum yaitu dengan menggunakan suhu tinggi pada waktu yang pendek dan perubahan secara fisik, pati lembab dan bahan berprotein yang menyebabkan bahan tersebut mengembang melalui kombinasi unik dari suhu tinggi, tekanan dan daya gerak. Teknologi ekstrusi dapat menghambat retrogradasi pati tinggi amilosa, meningkatkan stabilitas freeze thaw pati dan karakteristik gelatinisasi pada pati biji nangka (Zhang, 2018).

\section{MODIFIKASI KIMIA}

Modifikasi pati biji nangka secara kimia dapat dilakukan dengan memasukan gugus fungsional ke dalam molekul pati dengan cara substitusi dan atau ikatan silang dengan tujuan memperbaiki sifat fungsional pati. Sifat fungsional pati yang dapat diperbaiki diantaranya adalah kemampuan mengembang (swelling power) dan kelarutan pati; gelatinisasi; sifat pemastaan; sineresis; serta sifat termal pati (Naknaen, 2014); (N. Kittipongpatana et al., 2011); (O. S. Kittipongpatana \& Kittipongpatana, 2011). Adapun modifikasi pati biji nangka secara kimia dapat dilakukan dengan cara eterifikasi, oksidasi, dan ikatan silang (Naknaen, 2014); (O. S. Kittipongpatana \& Kittipongpatana, 2011); (Naknaen et al., 2017).

\section{Eterifikasi}

Proses eterifikasi yang umum digunakan pada pati yang digunakan dalam industri pangan adalah hidroksipropilasi. Agen hidroksipropilasi yang digunakan diantaranya adalah propilen oksida. Propilen oksida direaksikan dengan pati biji nangka untuk menginkorporasikan gugus hidroksipropil ke rantai polimer pati (Naknaen, 2014); (O. S. Kittipongpatana \& Kittipongpatana, 2011). (O. S. Kittipongpatana \& Kittipongpatana, 2011) menggunakan propilen oksida dengan konsentrasi rendah $(12 \mathrm{ml} / 100 \mathrm{~g}$ pati) sedangkan Naknaen (2014) menggunakan propilen oksida dengan beberapa tingkatan konsentrasi $(5 \mathrm{ml} / 100 \mathrm{~g}-50 \mathrm{ml} / 100 \mathrm{~g}$ pati).

Substitusi molar digunakan untuk menghitung jumlah mol gugus hidroksipropil yang berhasil diinkorporasi per unit glukosa. Peningkatan volume propilen oksida yang digunakan dalam hidroksipropilasi meningkatkan substitusi molar pada pati hidroksipropilasi yang dihasilkan (L. Wang et al., 2017). Merujuk pada (Naknaen, 2014), 
subsitusi molar pati biji nangka meningkat seiring dengan meningkatnya volume propilen oksida sampai dengan $40 \quad \mathrm{ml} \quad(\mathrm{p}<0,05)$ kemudian penambahan volume di atas $40 \mathrm{ml}$ tidak memberikan perbedaan substitusi molar yang signifikan. Gugus hidroksipropil terutama bereaksi dengan rantai pati pada area amorf yang sebagian besar terdiri dari amilosa. Semakin tinggi volume agen hidroksipropilasi yang digunakan maka akan semakin tinggi kesempatan kontak agen hidroksipropilasi dengan molekul pati sehingga semakin tinggi pula kesempatan agen hidroksipropilasi tersebut untuk bereaksi dan terinkorporasi pada rantai polimer pati (Naknaen, 2014).

Hidroksipropilasi tidak memberikan pengaruh pada kenampakan pati biji nangka. Pati biji nangka native dan hidroksipropilasi memiliki kenampakan halus, tidak berbau, dan memiiki warna putih pucat (O. S. Kittipongpatana \& Kittipongpatana, 2011). Berdasarkan pengamatan menggunakan $X$-ray Diffraction (XRD), pati biji nangka native memiliki karakteristik struktur kristalin dengan pola tipe A (O. S. Kittipongpatana \& Kittipongpatana, 2011); (Naknaen, 2014). Hidroksipropilasi tidak mengubah pola kristalin pati biji nangka namun menurunkan derajat kristalinitasnya seiring dengan meningkatnya konsentrasi propilen oksida yang ditambahkan. eterifikasi normalnya terjadi pada bagian amorf sehingga tidak mempengaruhi derajat kristalinitas pati. Namun, seiring meningkatnya konsentrasi propilen oksida yang digunakan pada modifikasi pati biji nangka dapat mempengaruhi bagian amorf dan kristalin yang menyebabkan penurunan derajat kristalinitas pada pati biji nangka hidroksipropilasi yang dihasilkan (Naknaen, 2014).

Perubahan sifat termal pati biji nangka hidroksipropilasi dipengaruhi oleh konsetrasi propilen oksida yang ditambahkan. Transisi gelatinisasi $\left(T_{o}, T_{p}, T_{e}\right)$ dan entalpi gelatinisasi $(\Delta \mathrm{H})$ berkurang seiring dengan bertambahnya konsentrasi propilen oksida yang digunakan. $\Delta \mathrm{H}$ dijadikan sebagai pengukur kristalinitas pati dan indikator hilangnya susunan molekuler granula pati. Penurunan $\Delta H$ disebabkan gugus hidroksipropil yang mengganggu susunan dobel heliks pada area amorf dan kristalin granula pati menghasilkan meningkatkan fleksibilitas structural (Naknaen, 2014).

Sifat termal berkaitan dengan daya pengembangan pati. Perlakuan hidroksipropilasi pada pati biji nangka dapat meningkatkan daya pengembangan jika dibandingkan dengan pati alaminya (O. S. Kittipongpatana \& Kittipongpatana, 2011); (Naknaen, 2014). Gugus hidroksipropil memiliki sifat hidrofilik sehingga kemampuan hidrasi granula pati hidroksipropilasi meningkat. Hal ini menyebabkan suhu gelatinisasi pada pati hidroksipropilasi lebih rendah dibandingkan dengan pati alami.

Pasta pati biji nangka hidroksipropilasi memiliki nilai transmitansi yang lebih tinggi dibandingkan dengan pati alaminya baik pada 
saat pasta di-gelatinisasi (O. S. diketahui dengan mengukur kandungan Kittipongpatana \& Kittipongpatana, 2011) maupun pada periode penyimpanan yang bervariasi (Naknaen, 2014). Hal ini mengidikasikan bahwa kecerahan pasta yang lebih baik pada pati dengan kandungan hidroksipropil yang lebih tinggi disebabkan oleh gugus hidroksipropil dapat menghambat pembentukan kembali ikatan inter- dan intramolekuler antar molekul pati. Kecerahan pasta ini bermanfaat pada saat pati diaplikasikan pada berbagai produk pangan untuk meningkatkan penerimaan konsumen.

\section{Oksidasi}

Proses oksidasi yang umum digunakan untuk menghasilkan pati oksidasi pada skala industri adalah oksidasi hipoklorit. Agen oksidasi yang dapat digunakan diantaranya sodium hipokorit dan kalsium hipoklorit (Naknaen et al., 2017); (Fonseca et al., 2015). Selain itu, dapat pula digunakan hidrogen peroksida (Dias et al., 2011). Reaksi biasanya dilakukan pada larutan basa rendah sampai sedang untuk menghasilkan gugus karboksil. Penggunaan pati oksidasi meningkat karena sifat pati oksidasi yang memiliki kemampuan membentuk lapisan film, stabilitas gel pada penyimpanan suhu rendah dan kecerahan pasta yang baik (Fonseca et al., 2015); (Naknaen et al., 2017).

Modifikasi pati biji nangka dengan cara oksidasi dilakukan dengan menambahkan sodium hipoklorit pada slurry pati biji nangka yang sudah diatur dalam kondisi basa (Naknaen, 2014). Derajat oksidasi dapat

karbonil dan karboksilnya. Hal ini karena selama oksidasi, gugus hidroksil pada molekul pati terutama pada C-2, C-3, dan C-6 berubah menjadi gugus karbonil dan kemudian menjadi gugus karboksil. Kandungan kabonil dan karboksil meningkat seiring dengan meningkatnya konsentrasi klorin aktif (Naknaen et al., 2017). Adapun jumlah karbonil dan karboksil pada pati oksidasi tergantung dari beberapa faktor diantaranya sumber pati, tipe agen oksidasi dan konsentrasinya, waktu, $\mathrm{pH}$, dan suhu reaksi (Fonseca et al., 2015).

Warna pati biji nangka setelah oksidasi lebih putih, ditandai dengan nilai $L^{*}$ pati oksidasi $(95,67-96,62)$ yang lebih tinggi dibandingkan dengan nilai $L^{*}$ pati native $(94,46)$ (Naknaen et al., 2017). Proses modifikasi dapat mengoksidasi pigmen dan protein sebelum mengoksidasi unit glukosa sehingga warna pat biji nangka yang dihasilkan setelah oksidasi menjadi lebih putih.

Seperti halnya pati biji nangka hidroksipropilasi, pati biji nangka oksidasi juga tidak mengubah pola kristalin pati biji nangka. Derajat kristalinitas pati menurun seiring dengan meningkatnya jumlah sodium hipoklorit yang ditambahkan. Hal ini dimungkinkan karena area kristalin mulai terpengaruh perlakuan penambahan klorin aktif selama oksidasi. Selain itu, pati biji nangka yang dioksidasi dengan konsentrasi klorin aktif yang lebih tinggi menyebabkan 
depolimerisasi rantai amilopektin yang lebih besar sehingga derajat kristalinitas pati semakin menurun (Naknaen et al., 2017).

Sifat termal pati biji nangka mengalami perubahan setelah diberi perlakuan oksidasi. Pati biji nangka oksidasi memiliki suhu onset ( $\mathrm{T}_{\mathrm{o}}$ ) yang lebih rendah dibandingkan pati alaminya (Naknaen et al., 2017). Hal ini karena melemahnya granula pati sehingga ikatan dobel heliks amilopektin mengalami rupture dengan lebih cepat. Pada konsentrasi klorin aktif rendah (1-3\%) daya pengembangan pati biji nangka setelah dioksidasi lebih rendah dari pati native, sedangkan pada konsentrasi yang lebih tinggi (4-5\%), daya pengembangan pati biji nangka oksidasi yang dihasilkan lebih tinggi dibandingkan pati alami (Naknaen et al., 2017). Hal ini dapat disebabkan karena granula pati oksidasi memiliki kemampuan menyerap air selama pemanasan namun tidak mampu menahan air selama dikenai gaya sentrifugasi (Dias et al., 2011). Pada konsentrasi klorin aktif yang lebih tinggi menghasilkan gugus karboksil yang belih tinggi. Keberadaan gugus karboksil membantu meningkatkan hidrasi sehingga dapat meningkatkan daya pengembangan (Naknaen et al., 2017).

\section{Ikatan silang}

Modifikasi ikatan silang pada pati dapat dilakukan menggunakan beberapa agen ikatan silang, hanya saja penggunaan agen ikatan silang harus disesuaikan dengan kegunaannya karena beberapa agen ikatan silang tidak diperbolehkan dalam industri pangan. beberapa agen ikatan silang yang umum digunakan diantaranya adalah sodium tripolipospat (STPP), sodium trimetapospat (STMP), dan epiklorohidrin (Wongsagonsup et al., 2014); (O. S. Kittipongpatana \& Kittipongpatana, 2011); (Xiao et al., 2012). Modifikasi ikatan silang juga dapat dikombinasikan dengan modifikasi lain seperti dengan modifikasi karboksimetilasi (N. Kittipongpatana et al., 2011).

Modifikasi ikatan silang pada pati biji nangka dilakukan dengan mencampurkan slurry pati dengan agen ikatan silang STMP dalam suasana basa kuat $(\mathrm{pH} 10,5)$ (O. S. Kittipongpatana \& Kittipongpatana, 2011). Sedangkan modifikasi pati gabungan karboksimetilasi dengan ikatan silang dilakukan dengan mereaksikan larutan asam kloroasetat dan STMP dengan pati biji nangka pada kondisi basa dengan bantuan panas dan pengadukan (N. Kittipongpatana et al., 2011). STMP menjadi agen ikatan silang yang banyak dipilih dalam industri pangan dan farmasi karena efisien dan memiliki toksisitas rendah serta masuk klasifikasi GRAS (generally recognized as safe) (Wongsagonsup et al., 2014); (N. Kittipongpatana et al., 2011). Pengukuran derajat ikatan silang dilakukan dengan mengukur kandungan pospat pada pati biji nangka setelah perlakuan. Kandungan pospat pati biji nangka ikatan silang adalah $0,26 \%$ yang setara dengan derajat kristalinitas 0,028 (O. S. Kittipongpatana \& Kittipongpatana, 2011). 
Modifikasi ikatan silang dan modifikasi gabungan ikatan silang dengan karboksimetilasi pada pati biji nangka tidak mengubah pola kristalin pati (Wongsagonsup et al., 2014); (N. Kittipongpatana et al., 2011). Hal ini, seperti yang telah disinggung sebelumnya bahwa umumnya modifikasi kimia terjadi pada daerah amorf sehingga hanya memberikan sedikit efek pada pola kristalin pati. Walaupun demikian, derajat kristalinitas pati biji nagka ikatang silang (33\%) menurun dibandingkan dengan derajat kristalinitas pati alaminya $(35,1 \%) \quad(\mathrm{N}$. Kittipongpatana et al., 2011).

Pati ikatan silang umumnya memiliki ketahanan panas yang tinggi yang ditandai dengan peningkatan sifat termal. (N. Kittipongpatana et al., 2011) melaporkan bahwa pati biji nangka dengan perlakuan ikatan silang mengalami sedikit penurunan yang signifikan pada tiap parameter sifat termal.

Pati biji nangka dengan perlakuan ikatan silang memiliki kecerahan pasta yang lebih rendah dibandingkan dengan pati alaminya. Hal ini disebabkan karena menurunnya kemampuan mengembang, terbatasnya dispersi dan kelarutan pati ikatan silang sehingga menurunkan kejernihan pasta selama perlakuan gelatinisasi (N. Kittipongpatana et al., 2011).

Penggunaan pati dengan tingkat ikatan silang yang tepat dapat menghasilkan pati dengan kemampuan pengembangan yang tinggi dan tidak mudah rupture sehingga dapat mengontrol sifat reologi bahan pangan. derajat ikatan silang yang tinggi tidak selalu baik untuk mengembangkan tekstur produk pangan karena tidak semua bahan pangan memerlukan pati dengan ketahanan panas yang tinggi (Wongsagonsup et al., 2014).

\section{MORFOLOGI GRANULA}

Morfologi granula pati biji nangka alami dan setelah modifikasi ditunjukkan oleh Gambar 1. (Dutta et al., 2011) melaporkan bahwa pati biji nangka alami memiliki bentuk yang beraneka ragam, bundar, trigonal dan tetragonal dengan ukuran 6-12 $\mu \mathrm{m}$. (O. S. Kittipongpatana \& Kittipongpatana, 2011) melaporkan bahwa SEM menunjukkan granula pati biji nangka alami memiliki bentuk bulat, ada yang seperti lonceng dengan permukaan yang mengkerut, ukuran partikel sebesar 5-10 $\mu \mathrm{m}$. Setelah mengalami modifikasi pregelatinisasi dan karboksimetilasi, granula pati menjadi pecah. Ukuran pati biji nangka termodifikasi secara oksidasi menjadi meningkat setelah oksidasi (Naknaen et al., 2017). Banyak penelitian menyebutkan bahwa tidak ada perubahan bentuk dan permukaan pada pati termodifikasi secara oksidasi. (Naknaen, 2014) menyebutkan juga tidak ada perubahan bentuk pada pati biji nangka termodifikasi secara eterifikasi (hidroksipropilasi) menggunakan propilen oksida. Pati biji nangka termodifikasi secara panas lembab dan annealing, granula menjadi lebih mengembang dan permukaan mengalami korosi (Bhattacharjya et al., 2015). 


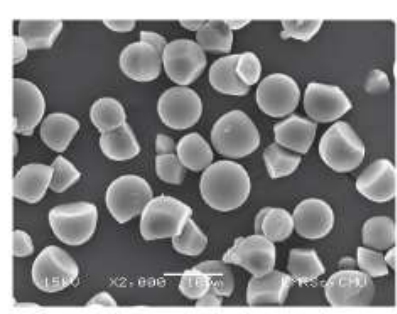

A

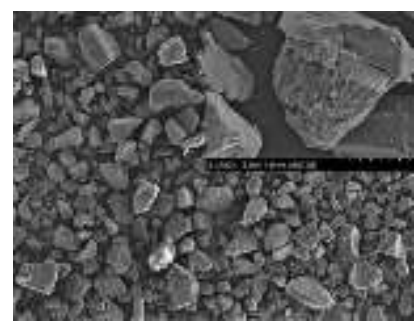

$\mathrm{C}$

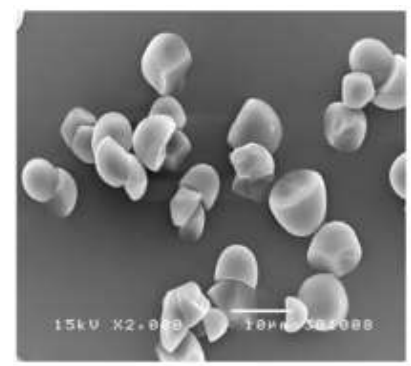

E

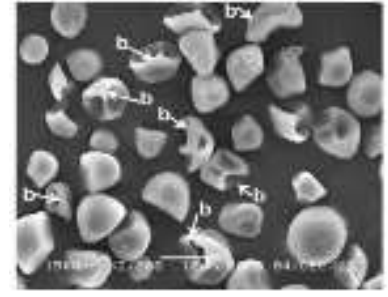

B

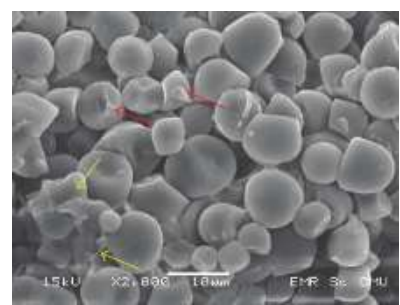

D

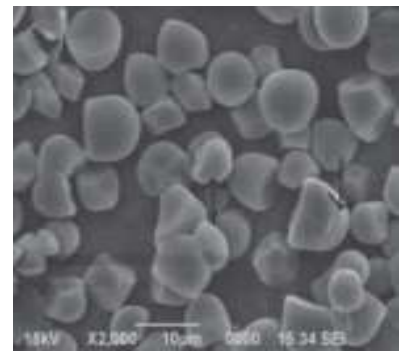

F

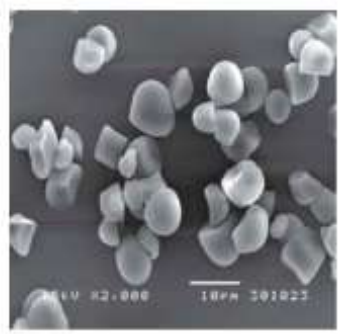

G

Gambar 1. A. Pati biji nangka alami (O. S.

Kittipongpatana \& Kittipongpatana, 2015),

Pati biji nangka termodifikasi secara B. Gelatinisasi parsial (Tran et al., 2015), C. Ekstrusi (Zhang et al., 2019) , D. Panas lembab (O. S. Kittipongpatana \& Kittipongpatana, 2015), E. Hidroksipropilasi (Naknaen, 2014), F. Annealing (Bhattacharjya et al., 2015), G. Oksidasi (Naknaen et al., 2017)

Pati biji nangka yang mengalami modifikasi panas lembab juga memiliki bentuk yang lebih tidak beraturan (O. S. Kittipongpatana \& Kittipongpatana, 2015).

\section{KESIMPULAN}

Modifikasi pati dapat dilakukan secara fisik dan kimia. Modifikasi pati secara fisik dilaporkan dapat menghasilkan perubahan karakteristik fungsional seperti penurunan viskositas, peningkatan kelarutan, penurunan tingkat pengembangan, peningkatan kapasitas pengikatan air, peningkatan kadar pati resisten seperti pada modifikasi pati biji nangka secara panas lembab, peningkatan tingkat kecernaan pati seperti pada modifikasi pati biji nangka metode ekstrusi. Modifikasi pati secara kimia dapat memperbaiki sifat fungsional pati seperti sifat termal, swelling power, dan kejernihan pasta tanpa mengubah pola kristalin pati. Pemilihan modifikasi kimia pada pati biji nangka dapat disesuaikan dengan kebutuhan dan karakteristik produk pangan yang diinginkan. Penggunaan agen substitusi dan atau ikatan silang untuk memodifikasi pati yang digunakan dalam industri pangan perlu memperhatikan toksisitas dan batas maksimal penggunaan serta residu yang diperbolehkan sesuai dengan regulasi yang ada.

\section{DAFTAR PUSTAKA}

Abbas, K. A., K. Khalil, S., \& Meor Hussin, A. S. (2010). Modified Starches and Their Usages in Selected Food Products: A Review Study. Journal of Agricultural Science, 2(2), 90-100. https://doi.org/10.5539/jas.v2n2p90

Ambigaipalan, P., Hoover, R., Donner, E., \& Liu, Q. (2014). Starch chain interactions within the amorphous and crystalline domains of pulse starches during heatmoisture treatment at different temperatures 
and their impact on physicochemical properties. Food Chemistry, 143, 175-184. https://doi.org/10.1016/j.foodchem.2013.07 .112

Bhattacharjya, B., Dutta, H., Patwari, K., \& Mahanta, C. L. (2015). Properties of annealed jackfruit (Artocarpus heterophyllus lam.) seed starch. Acta Alimentaria, 44(4), 501-510. https://doi.org/10.1556/066.2015.44.0021

Dias, A. R. G., Zavareze, E. D. R., Helbig, E., Moura, F. A. De, Vargas, C. G., \& Ciacco, C. F. (2011). Oxidation of fermented cassava starch using hydrogen peroxide. Carbohydrate Polymers, 86(1), 185-191. https://doi.org/10.1016/j.carbpol.2011.04.0 26

Dundar, A. N., \& Gocmen, D. (2013). Effects of autoclaving temperature and storing time on resistant starch formation and its functional and physicochemical properties. Carbohydrate Polymers, 97(2), 764-771. https://doi.org/10.1016/j.carbpol.2013.04.0 83

Dutta, H., Paul, S. K., Kalita, D., \& Mahanta, C. L. (2011). Effect of acid concentration and treatment time on acid-alcohol modified jackfruit seed starch properties. Food Chemistry, 128(2), 284-291. https://doi.org/10.1016/j.foodchem.2011.03 .016

Eke-Ejiofor, O. (2014). The Functional Properties of Starches, Physico-Chemical and Sensory Properties of Salad Cream from Cassava and Potatoes. International Journal of Nutrition and Food Sciences, 3(6), 567. https://doi.org/10.11648/j.ijnfs.20140306.2 2

Fonseca, L. M., Gonçalves, J. R., El Halal, S. L. M., Pinto, V. Z., Dias, A. R. G., Jacques, A. C., \& Zavareze, E. da R. (2015). Oxidation of potato starch with different sodium hypochlorite concentrations and its effect on biodegradable films. LWT - Food Science and Technology, 60(2), 714-720. https://doi.org/10.1016/j.lwt.2014.10.052

Kittipongpatana, N., Janta, S., \& Kittipongpatana, O. (2011). Preparation of cross-linked carboxymethyl jackfruit starch and evaluation as a tablet disintegrant. Pakistan Journal of Pharmaceutical
Sciences, 24(4), 415-420.

Kittipongpatana, O. S., \& Kittipongpatana, N. (2011). Preparation and physicochemical properties of modified jackfruit starches. LWT - Food Science and Technology, 44(8), 1766-1773.

https://doi.org/10.1016/j.lwt.2011.03.023

Kittipongpatana, O. S., \& Kittipongpatana, N. (2015). Resistant starch contents of native and heat-moisture treated jackfruit seed starch. Scientific World Journal, 2015. https://doi.org/10.1155/2015/519854

Li, S., Ward, R., \& Gao, Q. (2011). Effect of heat-moisture treatment on the formation and physicochemical properties of resistant starch from mung bean (Phaseolus radiatus) starch. Food Hydrocolloids, 25(7), 17021709.

https://doi.org/10.1016/j.foodhyd.2011.03.0 09

Madrigal-Aldana, D. L., Tovar-Gõmez, B., De Oca, M. M. M., Sáyago-Ayerdi, S. G., Gutierrez-Meraz, F., \& Bello-Pérez, L. A. (2011). Isolation and characterization of Mexican jackfruit (Artocarpus heterophyllus L) seeds starch in two mature stages. Starch/Staerke, 63(6), 364-372. https://doi.org/10.1002/star.201100008

Naknaen, P. (2014). Physicochemical, Thermal, Pasting and Microstructure Properties of Hydroxypropylated Jackfruit Seed Starch Prepared by Etherification with Propylene Oxide. Food Biophysics, 9(3), 249-259. https://doi.org/10.1007/s11483014-9347-2

Naknaen, P., Tobkaew, W., \& Chaichaleom, S. (2017). Properties of jackfruit seed starch oxidized with different levels of sodium hypochlorite. International Journal of Food Properties, 20(5), 979-996.

https://doi.org/10.1080/10942912.2016.119 1868

Polesi, L. F., \& Sarmento, S. B. S. (2011). Structural and physicochemical characterization of RS prepared using hydrolysis and heat treatments of chickpea starch. Starch/Staerke, 63(4), 226-235. https://doi.org/10.1002/star.201000114

Rengsutthi, K., \& Charoenrein, S. (2011). Physico-chemical properties of jackfruit seed starch (Artocarpus heterophyllus) and its application as a thickener and stabilizer 
in chilli sauce. $L W T$ - Food Science and

Technology, 44(5), 1309-1313. https://doi.org/10.1016/j.lwt.2010.12.019

Roy Chowdhury, A., Bhattacharyya, A. K., \& Chattopadhyay, P. (2012). Study on functional properties of raw and blended jackfruit seed flour (a non-conventional source) for food application. Indian Journal of Natural Products and Resources, 3(3), 347-353.

Tran, P. L., Nguyen, D. H. D., Do, V. H., Kim, Y. L., Park, S., Yoo, S. H., Lee, S., \& Kim, Y. R. (2015). Physicochemical properties of native and partially gelatinized highamylose jackfruit (Artocarpus heterophyllus Lam.) seed starch. LWT - Food Science and Technology, 62(2), 1091-1098. https://doi.org/10.1016/j.lwt.2015.01.054

Wang, L. F., Pan, S. Y., Hu, H., Miao, W. H., \& Xu, X. Y. (2010). Synthesis and properties of carboxymethyl kudzu root starch. Carbohydrate Polymers, 80(1), 174179.

https://doi.org/10.1016/j.carbpol.2009.11.0 08

Wang, L., Liu, X., \& Wang, J. (2017). Structural properties of chemically modified Chinese yam starches and their films. International Journal of Food Properties, 20(6), 1239-1250. https://doi.org/10.1080/10942912.2016.120 9775

Wongsagonsup, R., Pujchakarn, T.,
Jitrakbumrung, S., Chaiwat, W., Fuongfuchat, A., Varavinit, S., Dangtip, S., \& Suphantharika, M. (2014). Effect of cross-linking on physicochemical properties of tapioca starch and its application in soup product. Carbohydrate Polymers, 101(1), 656-665.

https://doi.org/10.1016/j.carbpol.2013.09.1 00

Xiao, H. X., Lin, Q. L., Liu, G. Q., \& Yu, F. X. (2012). A comparative study of the characteristics of cross-linked, oxidized and dual-modified rice starches. Molecules, 17(9), 10946-10957. https://doi.org/10.3390/molecules17091094 6

Zhang, Y., Zhang, Y., Li, B., Wang, X., Xu, F., Zhu, K., Tan, L., Dong, W., Chu, Z., \& Li, S. (2019). In vitro hydrolysis and estimated glycemic index of jackfruit seed starch prepared by improved extrusion cooking technology. In International Journal of Biological Macromolecules (Vol. 121). https://doi.org/10.1016/j.ijbiomac.2018.10. 075

Zhu, H., Zhang, Y., Tian, J., \& Chu, Z. (2018). Effect of a new shell material-Jackfruit seed starch on novel flavor microcapsules containing vanilla oil. Industrial Crops and Products, 112(October 2017), 47-52. https://doi.org/10.1016/j.indcrop.2017.10.0 60 